\title{
The effect of tomato consumption on selected protein and lipid metabolism parameters as well as on the oxidative and functional status of rat livers
}

\author{
V. Vasko, I. Kosieradzka ${ }^{1}$ and E. Sawosz \\ Warsaw Agricultural University, \\ Department of Animal Nutrition and Feed Science \\ Ciszewskiego 8, 02-786 Warszawa, Poland
}

\begin{abstract}
The effects of adding lyophilized tomato powder to diets for rats on selected biochemical protein and lipid metabolism parameters, as well as on the redox status of livers and blood were determined. For 4 weeks, 2 groups of male Wistar rats $(n=10)$ were fed isoproteinous diets ad libitum: control (casein) or experimental (10\% lyophilized tomato). Inclusion of tomatoes resulted in reduction $(\mathrm{P}<0.05)$ of superoxide dismutase activity in blood. The concentration of 8-oxo-2'-deoxyguanosine, the product of oxidative degradation of liver-cell DNA, was lower $(\mathrm{P}<0.01)$ than in controls, but the activities of serum aspargine and alanine transferases were higher $(\mathrm{P}<0.05)$ in the experimental rats. The influence of the diet on the other selected biochemical parameters of blood did not differ statistically between the groups.
\end{abstract}

KEY WORDS: tomato, rats, redox status, liver

\section{INTRODUCTION}

Tomato powder contains a natural carotenoid, lycopene $(1.1-1.3 \mathrm{mg} / \mathrm{g}$; Rodriguez-Amaya, 1999) that has a higher antioxidant potential than $\alpha$-tocopherol and $\beta$-carotene (Rao and Agarwal, 2000). Increased lycopene levels in blood may be associated with reduced oxidative damage to lipids, proteins and DNA (Agarwal and Rao, 2000) by reactive oxygen species (ROS). ROS react with cellular components causing oxidative damage to such critical cellular biomolecules as lipids, proteins and DNA. By protecting these biomolecules from the negative effects of ROS, tomato lycopene reduces the risk of cancer. The antioxidant activity of lycopene is highlighted by its singlet oxygen-quenching property and its ability to

\footnotetext{
${ }^{1}$ Corresponding author: e-mail: iwona.kosieradzka@sggw.pl
} 
trap peroxyl radicals (Shi, 2000) A higher lycopene status in the body may regulate gene functions and metabolism, as well as improve intercellular communication (Agarwal and Rao, 2000). Tomatoes also contain the steroidal glycoalkaloid, tomatine, which has been reported to form strong insoluble complexes with cholesterol in vitro and to be minimally absorbed from the digestive tract. This is also consistent with the reported low oral toxicity of tomatine compared with other glycoalkaloids (Friedman et al., 2000).

The objective of this study was to evaluate the effects of lyophilized tomatoes added to diets for rats on selected biochemical parameters of protein and lipid metabolism and on the redox status of their livers.

\section{MATERIAL AND METHODS}

The experimental material consisted of tomato fruits (Lycopersicum esculentum Mill) cultivar "Beta", cultivated in greenhouses. Ripe tomato fruits were cut, frozen $\left(-30^{\circ} \mathrm{C}\right)$ and freeze-dried.

Male Wistar rats with a mean body weight of $221.25 \mathrm{~g}$ were allotted to 2 groups $(\mathrm{n}=10)$ and kept in individual cages. The isoproteinous diets for control and experimental rats contained, respectively, \%: lyophilized tomato fruits 0,10 ; casein 16.5, 14.2; cellulose 4, 3; maize starch 70, 64.1. Both diets were supplemented with: oil 4; vitamin mixtures 1 , mineral mixtures 3.5 , choline chloride 0.2 , and DL-methionine 0.1 . At the end of the experiment the rats were fasted for $12 \mathrm{~h}$, weighed and euthanized by ketamine overdose, blood was sampled from hearts, the livers were removed, weighed, and frozen $\left(-70^{\circ} \mathrm{C}\right)$.

The concentrations of oxidative protein, lipid, and DNA degradation products were determined in liver tissue. $\mathrm{NO}_{3}^{-}$and $\mathrm{NO}_{2}^{-}$were assayed by HPLC (Waters), thiobarbituric acid reactive substances (TBARS) were measured colorimetrically (using 1.2.3.3.-tetraethoxypropane-TEP as a standard); 8-oxo-2'-deoxyguanosine (8-oxo-dG) was assayed in brain tissue using a Dionex HPLC with electrochemical (at $350 \mathrm{mV}$ ) and $\mathrm{UV}$ (at $254 \mathrm{~nm}$ ) detectors and a $250 \times 4.6 \mathrm{~mm}$ Supelcosil LC-18-S column (5 $\mu \mathrm{m}$ grain). The results are expressed as the number of 8-oxy-dG molecules per $10^{6}$ molecules of unmodified $\mathrm{dG}-8 \mathrm{odG} / 10^{6} 2 \mathrm{dG}$. Cholesterol, HDL, triglycerides, urea $\mathrm{N}$, total protein, asparagine transferase (AST) and alanine transferase (ALT) activities were determined in blood serum using a Vitros DT II (Johnson and Johnson, USA). The activities of antioxidant enzymes, i.e. superoxide dismutase (SOD) and glutathione peroxidase (GSHPx), were determined using kits from Randox Laboratories Ltd. The results were subjected to statistical analysis by single-factor analysis of variance ANOVA and Duncan's range test, using the Statgraphic 4.1 Plus software package. 


\section{RESULTS AND DISCUSSION}

Including lyophilized tomatoes into the diets for rats at a rate of $10 \%$ did not influence the content of total cholesterol, HDL or triglycerides in the blood serum. The differences between the values of selected biochemical parameters related to protein metabolism were also statistically insignificant (Table 1) and did not differ from the reference values, indicating that the metabolic functions of the experimental rats were adequate. Feeding the diets with the addition of tomatoes did, however, reduce the activity of antioxidant enzymes: that of superoxide dismutase (SOD) was statistically significantly lower in the blood of the experimental rats. Similar effects were also reported by Moreira et al. (2005). Inclusion of tomatoes did not influence the concentration of the products of oxidative degradation of lipids (thiobarbituric acid reactive substances - TBARS) and proteins $\left(\mathrm{NO}_{3}^{-}\right.$and $\mathrm{NO}_{2}^{-}$) in liver tissue.

Table 1. Concentrations of selected biochemical parameters in peripheral blood serum of rats, antioxidant enzyme activities (in plasma), concentrations of nitrite and nitrate, thiobarbituric acid reactive substances and 8-oxo-2'-deoxyguanosine in the liver tissue and relative liver weights

\begin{tabular}{|c|c|c|c|c|}
\hline \multirow{2}{*}{ Parameter } & \multicolumn{2}{|c|}{ Group } & \multirow{2}{*}{ SEM } & \multirow{2}{*}{$\mathrm{P}$} \\
\hline & control & experimental & & \\
\hline Total protein, g/dl & 6.4 & 6.5 & 0.123 & 0.659 \\
\hline Albumin, g/dl & 3.9 & 4.0 & 0.071 & 0.264 \\
\hline $\mathrm{N}$ urea, $\mathrm{mg} / \mathrm{dl}$ & 15.3 & 14.0 & 0.648 & 0.227 \\
\hline $\mathrm{HDL}, \mathrm{mg} / \mathrm{dl}$ & 46.0 & 39.5 & 3.283 & 0.193 \\
\hline Triglycerides, mg/dl & 53.0 & 55.0 & 0.894 & 0.648 \\
\hline Total cholesterol, $\mathrm{mg} / \mathrm{dl}$ & 70.8 & 77.5 & 7.587 & 0.544 \\
\hline $\mathrm{AST}, \mathrm{U} / \mathrm{L}$ & 262.5 & 359.8 & 22.928 & $0.017^{*}$ \\
\hline ALT, U/L & 31.00 & 49.5 & 5.087 & $0.032^{*}$ \\
\hline GSH-Px, U/ml & 141.43 & 137.15 & 6.680 & 0.663 \\
\hline $\mathrm{SOD}, \mathrm{U} / \mathrm{ml}$ & 198.6 & 138.6 & 12.762 & $0.010^{*}$ \\
\hline TBARS, mmol/g & 0.2834 & 0.2847 & 0.000 & 0.074 \\
\hline $\mathrm{NO}_{2} \mathrm{NO}_{3} \mathrm{mg} / \mathrm{kg}$ & 3.5 & 3.6 & 0.034 & 0.168 \\
\hline 8-oxo-2'-deoxyguanosine, $8 \mathrm{odG} / 10^{6} 2 \mathrm{dG}$ & 7.8230 & 6.4848 & 0.077 & $0.000^{* *}$ \\
\hline Liver weight, $\mathrm{g} / 100 \mathrm{~g}$ body weight & 2.81 & 2.73 & 0.066 & 0.906 \\
\hline
\end{tabular}

means with different superscripts are significantly different. ${ }^{*}-\mathrm{P}<0.05 ;{ }^{* *}-\mathrm{P}<0.01$

A statistically significant decrease $(\mathrm{P}<0.01)$ in the liver 8-oxo-dG concentration was found in rats fed the tomato diet, as compared with control animals fed the standard casein diet (Table 1). It is likely that the activity of the experimental diet preventing oxidative degradation of DNA results from the activity of lycopene and carotenoids. Nevertheless, the reaction of the experimental rats may also result from the presence of some other biologically active dietary substances, diversified composition of fibre, easily digestible carbohydrates, and the possibility that they 
may influence the composition of digestive tract microflora as well as the activity of digestive enzymes, etc. Feeding diets containing lyophilized tomatoes resulted in statistically significantly $(\mathrm{P}<0.05)$ higher activities of asparagine transferase (AST) and alanine transferase (ALT) in the serum of rats in the experimental group (Table 1). The increase of AST and ALT values may be related to the presence of substances that have some toxic characteristics (e.g., tomatin, the glycoalkaloid present in tomatoes). The values of the other biochemical indicators do not indicate any metabolic disorders or damage of liver tissue (Friedman et al., 2000).

\section{CONCLUSIONS}

The results of this experiment suggest that the components of tomato fruits, especially biologically active substances with antioxidant properties, may protect liver cell DNA from degradation, even though they did not raise the concentrations of antioxidant enzymes in blood. The substantial percentage of tomatoes (in relation to the diet dry matter) did, however, increase the activity of the hepatic enzyme system.

\section{REFERENCES}

Agarval S., Rao A.V., 2000. Tomato lycopene and its role in human health and chronic diseases. Nutrition 163, 739-744

Friedman M., Fitch T.E., Yokoyama W.E., 2000. Lowering of plasma LDL cholesterol in hamsters by the tomato glycoalkaloid tomatine. Food Chem. Toxicol. 38, 549-553

Moreira E.A.M., Fagundes R.L.M., Filho D.W., Neves D., Sell F., Bellisle F., Kupek E., 2005. Effects of diet energy level and tomato powder consumption on antioxidant status in rats. Clin. Nutr. 24, 1038-1046

Rao A.V., Agarval S., 2000. Role of antioxidant lycopene in cancer and heart disease. J. Amer. College Nutr. 5, 563-569

Rodriguez-Amaya D.B., 1999. Latin American food sources of carotenoids. Arq. Latinoamer. Nutr. $49,74-84$

Shi J., 2000. Lycopene in tomatoes: chemical and physical properties affected by food processing. Crit. Rev. Food Sci. Nutr. 40, 1-42 